Niniejsza publikacja jest dostępna na licencji Creative Commons. Uznanie autorstwa-Użycie niekomercyjne-Bez utworów zależnych 3.0 Polska. Pewne prawa zastrzeżone na rzecz autora. Zezwala się na wykorzystanie publikacji zgodnie z licencja - pod warunkiem zachowania niniejszej informacji licencyjnej oraz wskazania autora jako właściciela praw do tekstu. Treść licencji jest dostępna na stronie: http://creativecommons.org/licenses/by-nc-nd/3.0/pl/

Lingwistyka Stosowana 24: 4/ 2017, 37-43

\author{
Urszula BUKOWSKA-PELC
}

Uniwersytet Śląski

\title{
Precyzja języka prawnego jako przykład precyzji języka fachowego
}

\begin{abstract}
:
Legal language precision as an example of specialised language precision

The purpose of the paper is to present how the basic assumption of the professional language, namely precision, is implemented in legal texts. The paper focuses on language structures that are characteristic of the legal language but at the same time affect its precision. Some examples include ambiguous terms, or unclear and underspecified expressions. The paper concentrates mainly on analysing legal definitions as a way of avoiding ambiguity as well as on the manner of building correct definitions. The author indicates which categories of errors should be avoided in constructing legal definitions (vicious circle of definition; defining the unknown by the unknown; definition irrelevance) in order to make a legal text clear. Given that legal norms define orders, prohibitions and permits, precision of the language used is of paramount importance. For it is precision that influences interpretation as well as translation to foreign languages.
\end{abstract}

\section{Wstęp}

W polskiej juryslingwistyce wyróżnia się za Bronisławem Wróblewskim język prawny i język prawniczy (zob. B. Wróblewski 1948: 54). Język prawny jest językiem, którym napisane są akty normatywne np. ustawy, rozporządzenia. Natomiast język prawniczy jest językiem doktryny prawniczej. Należy tutaj wspomnieć, że podział ten jest charakterystyczny tylko dla kultury polskiej, ponieważ w realiach na przykład niemieckich, nie wprowadza się rozróżnienia między językiem prawniczym i prawnym, oba te terminy zostają określone jako juristische Fachsprache, co w wolnym tłumaczeniu można określić, jako prawny/prawniczy język fachowy. W niniejszym artykule chciałabym się skoncentrować na języku prawnym, w związku z faktem, że na co dzień pojawia się problem interpretacji aktów prawnych i stawia się pytanie o precyzję języka, w którym one są napisane.

Trzeba jednak podkreślić, że wśród prawników oraz językoznawców istnieje spór dotyczący lingwistycznego statusu języka prawnego. Tomasz Gizbert- Studnicki w pracy pod wymownym tytułem $C z y$ istnieje język prawny zanegował wyodrębnienie języka prawnego w lingwistycznym znaczeniu (langue) (zob. T. Gizbert-Studnicki 1979: 60). Twierdził, że język prawny daje się wyodrębnić jako rejestr standardowego języka tylko przy liberalnym rozumieniu rejestru językowego. Poglądy, że rejestry 
językowe nie są wyróżnione na płaszczyźnie reguł (langue) lecz na płaszczyźnie wykonawstwa językowego (parole), zostały skrytykowane (zob. F. de Saussure 2002). Barbara Kielar broni statusu rejestrów językowych, a w konsekwencji języka prawnego, jako tzw. subjęzyków, rozumianych jako podsystemy reguł wyróżnionych w ramach danego systemu językowego (zob. B. Kielar 1979). Leksykę prawniczą należy traktować jako rozszerzenie systemu leksykalnego języka standardowego, powstałym wskutek pojawienia się nowego obszaru tematycznego (T. Gizbert-Studnicki 1979: 59). Analizę sporu o lingwistyczny status języka prawnego szczegółowo przedstawił Klaudiusz Brodziak w swojej pracy pt. O lingwistycznym statusie języka prawnego (K. Brodziak 2004).

Wyżej wymienione podejścia do języka prawnego należy skonfrontować z licznymi definicjami języka specjalistycznego $\mathrm{w}$ literaturze przedmiotu. W niniejszym artykule szczególnie warto zwrócić uwagę na dwie wybrane definicje. Lothar Hoffmann twierdził, że język specjalistyczny jest zespołem zjawisk językowych z określonej sfery komunikacji, który jest ograniczony przez specyficzne cele, intencje i warunki (L. Hoffman 1976: 170). Jerzy Pieńkos uważa, że język specjalistyczny jest czymś więcej aniżeli tylko rejestrem, stylem i słownictwem specjalistycznym. W języku specjalistycznym zauważa się wyraźną tendencję do definiowania pojęć, do kontrolowania polisemii, eliminacji synonimów oraz do upraszczania składni, neutralizowania afektywności oraz przyswajania znacznej liczby skrótów (zob. J. Pieńkos 1999: 71-72). Jerzy Pieńkos wymienia jako specyficzne cechy języka specjalistycznego w płaszczyźnie tekstowej zwięzłość, precyzję, depersonalizację autora. Uważam, że po analizie powyższych definicji, można odpowiedzieć twierdząco na pytanie czy język prawny jest językiem specjalistycznym.

\section{1. Środki do osiągnięcia precyzji}

Wielu językoznawców i prawników uważa, że język prawny jako język specjalistyczny, fachowy powinien charakteryzować się precyzją, jednoznacznością i zwięzłością (K. Siewiert 2010: 73). Jednakże wysoki stopień abstrakcyjności norm prawnych często utrudnia ich interpretację. Według Jerzego Pieńkosa ze wszystkich języków specjalistycznych język prawny uchodzi za ten, w którym panuje największa polisemia, która jest przeszkodą w osiągnięciu precyzji (J. Pieńkos 1999: 254). Dlatego tak trudnym zadaniem jest przekład tekstów prawnych. Często zdarza się, że pewne pojęcie funkcjonuje $\mathrm{w}$ jednym języku prawnym i nie ma odpowiednika $\mathrm{w}$ drugim.

Istotne dla tekstów prawnych jest zjawisko, które polega na tym, że w ramach jednego porządku prawnego, termin występuje w różnych znaczeniach, w poszczególnych gałęziach prawa. Przykładem może być rozumienie pojęcia winy w prawie karnym oraz $\mathrm{w}$ prawie cywilnym, pojęcia kary $\mathrm{w}$ prawie karnym lub w prawie administracyjnym. W oparciu o teorię stworzoną przez niemieckiego lingwistę i traduktologa Dietera Möhna, Julian Maliszewski (J. Maliszewski 2003) zwraca uwagę na sferę interleksykalną, ale również na intraleksykalną sferę terminologii specjalistycznej. Zdarza się, że dwa terminy, które wywodzą się z różnych gałęzi prawa w danym języku obcym brzmią identycznie. To również stanowi trudność tłumaczenia tekstów 
prawnych na inne języki. Aby dokonać prawidłowego tłumaczenia thumacz musi zdawać sobie sprawę z jakiej gałęzi prawa tłumaczy tekst i zastosować stosowną terminologię.

\author{
Przykłady z języka niemieckiego: \\ Rückerstattung \\ prawo karne: zwrot zagarniętego mienia \\ prawo gospodarcze: restytucja \\ Zulassung \\ prawo gospodarcze: dopuszczenie np. dowodu \\ prawo administracyjne: zezwolenie
}

Aby tekst prawny był precyzyjny istnieje założenie interpretacyjne, że nie występują w tekstach prawnych synonimy i homonimy. W konsekwencji dwóm różnokształtnym (co do formy) wyrazom lub wyrażeniom nadaje się różne znaczenie. Dobrym tekstem w języku prawnym jest tekst, który rzadko odwołuje się do określeń specjalistycznych, zapożyczeń obcojęzycznych (S. Wronkowska/ M. Zieliński 2012: 37). W praktyce jednak na przykładzie polskich tekstów prawnych można zauważyć, że ta zasada nie jest przestrzegana i pojawiają się nazwy obce (np. monitoring, implementacja) mimo, że istnieją polskie odpowiedniki (S. Lewandowski et al. 2010: 56).

$\mathrm{W}$ tekstach prawnych rzadko mamy do czynienia z eufemizmami, wyrażeniami nacechowanymi emocjonalnie. Celem jest ukazanie obiektywności i neutralności. Ponadto $\mathrm{w}$ tego typu tekstach nie pojawiają się wyrażenia żargonowe lub wulgarne. W praktyce należy się liczyć z możliwością występowania błędów w tym obszarze.

Mając powyższe na uwadze jednym ze środków usuwania wieloznaczności jest posługiwanie się definicjami legalnymi. Według językoznawcy Zenona Weigta idealna definicja powinna być krótka, prosta, precyzyjna i wykluczać polisemię (Z. Weigt 2005: 363). Prawnicy - Sławomir Lewandowski i Hanna Machińska wyróżniają podstawowe reguły, które winna zachować prawidłowa definicja (S. Lewandowski et al. 2010: 54-60). Wśród nich możemy wymienić zasadę, iż definicja nie może zawierać terminu definiowanego. Definicja nie może być sformułowana w wyrazach o znaczeniu niejasnym, obrazowym lub wieloznacznym. Definicja musi ściśle odpowiadać gatunkowi definiowanemu.

Analizując kwestię precyzji należy wspomnieć, że problematykę definicji reguluje $\S 146$ ust. 1 Załącznika do rozporządzenia Prezesa Rady Ministrów z dnia 20 czerwca 2002 r. Zasady Techniki Prawodawczej (tekst jednolity, Dz. U. 2016, poz. 283). Według niego:

W ustawie lub innym akcie normatywnym formułuje się definicję danego określenia, jeżeli:

1) dane określenie jest wieloznaczne;

2) dane określenie jest nieostre, a jest pożądane ograniczenie jego nieostrości;

3) znaczenie danego określenia nie jest powszechnie zrozumiałe;

4) ze względu na dziedzinę regulowanych spraw istnieje potrzeba ustalenia nowego znaczenia danego określenia. 
Mając powyższe na względzie definiujemy, kiedy dane wyrażenie jest wieloznaczne. Trzeba mieć na uwadze, że nie jest możliwe całkowite wyeliminowanie nieostrości z języka prawnego, w związku z tym, że opiera się on na języku naturalnym. Często jednak wyrażenia jednoznaczne w języku potocznym nabierają wieloznaczności poprzez różne definiowanie w kilku aktach prawnych. $Z$ przytoczonego przepisu wynika również, że polski ustawodawca dopuszcza nieostrość pojęć, która nie jest postrzegana jako wada, pozostawiając pewną przestrzeń dla interpretacji danego przepisu (zob. S. Wronkowska/ M. Zieliński 2012: 283). Celem takiego działania jest pozostawienie organom stosującym prawo tzw. luzu interpretacyjnego. Ustawodawca nie jest w stanie przewidzieć wszystkich sytuacji życiowych. Podstawowym środkiem zapewnienia jednoznaczności określeń języka powszechnego $\mathrm{w}$ tekście prawnym jest umieszczanie ich w odpowiednim kontekście językowym (S. Wronkowska/ M. Zieliński 2012: 282).

Punkt trzeci przytoczonego cytatu dotyczy słownictwa z zakresu języków profesjonalnych. Coraz częściej mamy do czynienia z definicjami terminów, które służą wyłącznie wykwalifikowanym specjalistom.

W ostatnim punkcie mowa jest o nadawaniu nowego znaczenia określeniom, które już istnieją. W tym przypadku tworzymy definicję projektującą, która ustanawia jakąś regułę znaczeniową, która będzie odpowiednia dla danego aktu prawnego. Jeśli definicja ustala nowe znaczenie mamy do czynienia z definicją konstrukcyjną (S. Lewandowski et al. 2010: 56).

$\S 147$ nakazuje raz zdefiniowany termin w danym akcie prawnym używać w tym samym znaczeniu w obrębie całego aktu. Dopuszcza się zamieszczenie dwóch różnych definicji w obrębie jednego aktu prawnego, pod warunkiem, iż adresat normy nie będzie miał problemów z ustaleniem ich zakresów.

Definicje można podzielić biorąc pod uwagę różne kryteria. W przedmiotowym artykule chciałabym się skupić wyłącznie na podziale definicji ze względu na to, do czego się odnoszą. Mając to na uwadze wyróżniamy definicje realne oraz definicje nominalne, zwane inaczej terminologicznymi (S. Lewandowski et al. 2010: 62). Definicja realna wychodzi z rzeczywistości, którą odzwierciedla, określa dane pojęcie prawne. Wypracowuje pojęcie ogólne, jest definicją obiektywną i treściwą. Definicja realna sformułowana jest $\mathrm{w}$ języku I stopnia, dlatego określa się również mianem definicji międzyjęzykowej (S. Lewandowski et al. 2010: 63). Punktem wyjścia definicji nominalnej jest natomiast wyraz mający być jej przedmiotem, którego należy używać w określonym znaczeniu (J. Pieńkos 1999: 88). Definicja nominalna zwana jest też definicją metajęzykową, ponieważ nie odnosi się bezpośrednio do przedmiotu, lecz dotyczy języka, w którym zostały użyte definiowane nazwy (S. Lewandowski et al. 2010: 62).

Joanna Grzelak podkreśla, iż definicje legalne odcinaja język tekstu, w przypadku ustaw całej grupy tekstów, od języka ogólnego i kreuja znaczenie użytych w tekstach pojęć, często zmieniajac lub zawężając zakres znaczeniowy pojęcia istniejacy w języku ogólnym (J. Grzelak 2010: 85).

Warto również wspomnieć jakich błędów należy unikać przy budowaniu definicji. Można wyróżnić następujące kategorie błędów: circulus in definiendo, błąd ignotum 
per ignotum oraz możemy się zetknąć z nieadekwatnością definicji.

Circulus in definiendo (błędne koło w definiowaniu) polega na określaniu definiowanego wyrazu poprzez odwołanie się do niego samego. Błąd ten może przyjąć dwie postacie. Pierwsza postać to błąd idem per idem (to samo przez to samo, błędne koło bezpośrednie), występuje wtedy, gdy w definiensie pojawia się wyrażenie występujące w definiendum.

Przyklad:

Straż miejska jest to straż, która strzeże porządku miejskiego.

W drugim przypadku powstaje błędne koło pośrednie, gdy jedno wyrażenie definiujemy za pomocą następnego wyrażenia, które z kolei definiujemy za pomocą następnego wyrażenia, na końcu zwracamy się ku wyrażeniu pierwotnemu (J. Grzelak 2010: 69).

Przyktad:

Sędzia to osoba uprawniona do wydawania wyroków sądowych. Wyrok sądowy jest to decyzja sędziego.

Natomiast błąd ignotum per ignotum (nieznane przez nieznane) polega na zamieszczeniu definiensie wyrażenia, które, podobnie jak wyrażenie definiowane, jest nieznane odbiorcy definicji.

Przyktad

Polopiryna to kwas acetylosalicylowy (Z. Ziembiński 2001: 52).

Z nieadekwatnością definicji mamy do czynienia, gdy zakres definiendum nie jest zamienny z zakresem definiensa. Możemy wyróżnić sytuację kiedy zakres definiensa jest szerszy od zakresu definiendum; zakres definiensa jest węższy od zakresu definiendum; zakresy definiensa i definiendum krzyżują się.

Przyktady:

definicja ,za szeroka”

Prokurator jest pracownikiem prokuratury.

definicja „za wąska”

Uczestnikiem procesu sądowego jest prokurator.

błąd krzyżowania się zakresów

Czyn karalny jest to zaniechanie.

Ponadto możemy mieć jeszcze do czynienia $\mathrm{z}$ błędem przesunięcia kategorialnego. Błąd ten polega na tym, że definiendum i definiens reprezentują różne kategorie ontologiczne. Wyróżniamy takie kategorie ontologiczne jak: rzeczy, cechy, zbiory i sytuacje (zob. Z. Ziembiński 2001: 53-54).

Przyklad:

Czernią nazywamy każdą rzecz czarną.

Na precyzję tekstu prawnego wpływa użycie przez ustawodawcę zwrotów niedookreślonych znaczeniowo. Według Macieja Zielińskiego każde prawotwórstwo oscy- 
luje między skrajnością pewności prawa a skrajnościa jego elastyczności (M. Zieliński 1999: 59). Ustawodawca dopuszcza nieostrość pojęć ponieważ jego celem jest pozostawienie pewnej przestrzeni dla interpretacji danego przepisu. Nieostrość definicji wskazana jest np. w prawie cywilnym (np. zasady wspólżycia społecznego, poważne niebezpieczeństwo osobiste), ale jest niedopuszczalna w prawie karnym. Używane przez prawodawcę nazwy nieostre nazywa się klauzulami generalnymi. Stosowanie ich pozwala uniknąć zbytniej kazuistyczności norm. B. Wróblewski pisał, że sama definicja może się okazać szkodliwa w praktyce. Uzyskanie w ten sposób ścistości języka może się stać hamulcem do przystosowania przepisów do życia w drodze wykładni (B. Wróblewski 1948: 91). Praktyka orzecznicza daje nam dopiero odpowiedź czy w danym przypadku stan rzeczy mieści się w zakresie klauzuli generalnej.

\section{Podsumowanie i wnioski}

Abstrahując od sporu o lingwistyczny status języka prawnego jest to na pewno specyficzna forma języka (W. Maciejewski 2007: 133). W związku z tym, że bazą języka prawnego jest język ogólny mamy do czynienia w nim ze zjawiskiem polisemii. Biorąc pod uwagę, że język prawny wyraża normy, które są formułowane w celu zmiany stanu rzeczy, kształtuje zakazy, nakazy lub dozwolenia, precyzja odgrywa ważną rolę. Jednakże zauważa się, że nieostrość używanych terminów może mieć charakter zamierzony (klauzule generalne) albo występować na skutek usterek legislacyjnych. Ponadto normy prawne charakteryzują się wysokim stopniem abstrakcyjności, co często przyczynia się do problemów interpretacyjnych oraz trudności przekładu tekstów prawnych.

Środkiem, który ma ograniczyć ryzyko wieloznaczności jest formułowanie definicji legalnych (ustawowych). Aby cel ograniczenia wątpliwości został osiągnięty, definicje muszą jednakże zostać sformułowane zgodnie z Zasadami Techniki Prawodawczej. W praktyce widać, że polski ustawodawca nie zawsze się do nich stosuje.

\section{Bibliografia}

Brodziak, K. (2004), O lingwistycznym statusie języka prawnego, (w:) „Studia Prawnicze" $1,110-124$.

Gizbert-Studnicki, T. (1979), Czy istnieje język prawny? (w:) „Państwo i Prawo” 3, 49-60.

Grzelak, J. (2010), Polski język prawa w perspektywie glottodydaktycznej. Poznań.

Hoffmann, L. (1976), Kommunikationsmittel Fachsprache (Forum fur Fachsprachenforschung 1). Berlin.

Kielar, B. (1979), W obronie koncepcji ,języka prawnego" jako rejestru języka naturalnego, (w:) „Państwo i Prawo” 8/9, 172-173.

Lewandowski, S./ H. Machińska/ A. Malinowski/ J. Petrel (2010), Logika dla prawników. Warszawa. 
Maciejewski, W. (2007), Próba semiotycznej analizy wspótczesnego języka prawnego, (w:) A. Mróz/ M. Pawelec/ A. Niewiadomski (red.), Współczesny język prawny i prawniczy. Warszawa, 115-134.

Maliszewski, J. (2003), Pragmatyka leksykalna w przekładzie prawnym i prawniczym. Wokót zagadnień prawniczego języka specjalistycznego, (w:) J. Maliszewski (red.), Wybrane aspekty przekładu literackiego i specjalistycznego (Tłumaczenie, Przekład, Komunikacja). Częstochowa.

Pieńkos, J. (1999), Podstawy juryslingwistyki. Język w prawie - prawo w języku. Warszawa.

Pieńkos, J. (2003), Podstawy przektadoznawstwa. Od teorii do praktyki. Kraków.

de Saussure, F. (2002), Kurs językoznawstwa ogólnego. Warszawa.

Siewert, K. (2010), Semantische Analyse juristischer Fachwörter am Beispiel der Terrminologie des Handelsrechts. Eine deutsch-polnische kontrastive Studie. Bydgoszcz.

Weigt, Z. (2005), Das Präzisieren in deutschen und polnischen normativen Texten, (w:) M. Wierzbicka/ M. Sieradzka/ J. Homa (red.), Moderne deutsche Texte (Danziger Beiträge zur Germanistik 16). Rzeszów.

Wronkowska, S./ M. Zieliński (2012), Komentarz do zasad techniki prawodawczej $z$ dnia 20 czerwca $2002 r$. Warszawa.

Wróblewski, B. (1948), Język prawny i prawniczy (Polska Akademia Umiejętności Kraków 3). Kraków.

Zieliński, M. (1999), Języki prawne i prawnicze, (w:) W. Pisarek (red.), Polszczyzna 2000 Orędzie o stanie języka na przełomie tysiącleci. Kraków, 50-74.

Ziembiński, Z. (2001), Logika praktyczna. Warszawa. 